\title{
Design and Production of Smart Wearable Textile Products Using Layered Manufacturing Technology with Photovoltaic Energy
}

DOI: $10.46932 / \mathrm{sfjdv2n2-040}$

Received in: january 1st, 2020

Accepted in: March 30th, 2020

\author{
Ilker Ertuna \\ R\&D Center, Menderes Tekstil Denizli, Turkey \\ Yusuf Güngör \\ Design Center, Menderes Tekstil Denizli, Turkey \\ Fatma Karaoğlu \\ $R \& D$ Center, Menderes Tekstil Denizli, Turkey \\ fatmaipek@arge.menderes.com \\ Nazlı Dindar \\ $R \& D$ Center, Menderes Tekstil Denizli, Turkey \\ nazlidindar@arge.menderes.com \\ Uğur Can Topçu \\ $R \& D$ Center, Menderes Tekstil Denizli, Turkey \\ Gökhan Çaliş \\ Creative Design Department, Menderes Tekstil , Denizli, Turkey \\ Doç. Dr. Ceren Göde
}

Machinery and Metal Technologies Department, Pamukkale University, Denizli, Turkey

\begin{abstract}
Smart textiles are used in a wide range of areas, such as defense industry, security, medicine, health, aviation, space sciences, environment, energy, biotechnology, agriculture, food, cosmetics and fashion design. In this study, with the progress of technology in the area of the wearable smart textile industry, 3D manufacturing which has started to take place in the industry as a new manufacturing method or in other words layered manufacturing practices are discessed. For this purpose, a solar panel was placed in the 3D printed material obtained by FDM method, one of the layered manufacturing methods, and integrated into the textile material and to charge our electronic devices from photovoltaic energy was explained. It is aimed to produce, using the knowledge gained as a result of the study, smart textile products that facilitate human life with 3D printed materials obtained from filaments with conductive additive.
\end{abstract}

Keywords: Smart textiles, FDM method, photovoltaic, communication, layered manufacturing 


\section{INTRODUCTION}

Smart Textiles; are materials that react by perceiving those stimulants when interfered with external effects such as force, temperature, heat, light, chemical reactions, electricity, and magnetic. Smart textiles are materials that can show change and react to only one of the factors mentioned above but also can show change and react to more than one factor.

Wearable technologies are called an adaptation of textile materials and clothing in a way that supports vital activities of humans such as senses, movement, communication, taking action, adapting to environmental conditions. Wearable technologies developed to provide superior quality and functionality to clothing are generally smart materials with electronic conductivity, produced by embedding microprocessors, LEDs (Light Emitting Diodes), GPS components, various sensors and access systems into a fabric.

Data from the wearer and environmental factors are based on electronic software; therefore, they identify the factors that allow measurement or processing. These factors stimulate the senses of the person who is wearing the clothing or looking at it. Examples of factors that activate the five senses are given in Table 1. [1]

\begin{tabular}{|l|l|}
\multicolumn{2}{l}{ Table 1. Sensory stimulation factors } \\
\begin{tabular}{|l|l|}
\hline Sense: & Factors: \\
\hline Sight & $\begin{array}{l}\text { LEDs, thermochromic pigments, } \\
\text { photochromic pigments, electronic wires, } \\
\text { screens }\end{array}$ \\
\hline Hearing & Speaker, electric bell \\
\hline Touch & Motors, conductive yarns, conductive fabrics \\
\hline $\begin{array}{l}\text { Taste/Smel } \\
1\end{array}$ & Flavored microcapsules \\
\hline
\end{tabular}
\end{tabular}

3D printers are a technological innovation that combines material, design and manufacturing processes. Unlike traditional machining or other manufacturing method or chipless manufacturing based on cutting from the block to create smaller material, the technology obtained by laying the pieces, many melted thin layers (micron level) layer by layer is called layered manufacturing (LM) or rapid prototyping (RP). There is a manufacturing geometry from the bottom layer (base) upwards. Many different materials can be used in layered manufacturing. Plastic, ceramic, metal, glass, chocolate, wood and carbon fiberadded products can be given as examples. The materials are melted directly with heat or pulverized, melted in the desired geometry with $\mathrm{CO} 2$ or fiber-optic lasers and then cooled in a very short time to solidify [2].

Many devices that we use in our daily life work with electrical energy. Perhaps photovoltaic technology is one of the most salient among renewable and clean energy technologies, which enables the 
generation of electrical energy using unlimited solar energy. Photovoltaics produce an energy at different capacities and used in space applications, building exterior coatings, roofs, tents, jackets and similar textile materials, traffic signaling, communication systems, concentrators. Photovoltaic textile is obtained by integrating a photovoltaic structure that generates electrical energy using sunlight and integrating it into the textile by placing pieces on the textile structure or by producing photovoltaic fibers, yarns and fabrics [3-4].

\section{MATERIAL AND METHOD}

In layered manufacturing, there are many categories and production methods suitable for different materials and requirements. Essentially; they can be categorized as liquid, powder, and solid-based methods. Using method one of the solid-based methods and called Fused Deposition Modeling (FDM).

\begin{tabular}{|l|}
\hline Figure 1. FDM layered manufacturing stages \\
\hline - Creating a 3D Cad Model \\
\hline$\bullet$ Converting a 3D Cad Model to Stl Format \\
\hline - Slicing the Stl File in Thin Layers \\
\hline$\cdot$ Constructing the Piece Layer by Layer \\
\hline - Cleaning and Finishing \\
\hline
\end{tabular}

Unlike powder and liquid-based methods, a plastic (thermoplastic) material is extruded through a nozzle that tracking the cross-sectional geometry of the piece in the FDM method. Model material is in the form of a thin plastic wire reel like a fish line. This reel is called filament (Figure 2). Sometimes, plastic granules are also used that fed from the chamber instead of filament. The nozzle contains a heating device to keep the thermoplastic at a temperature just above its melting point in that way the plastic easily flows over the nozzle and a layer is formed. After flowing from the nozzle, the plastic suddenly hardens with the help of fans and sticks to the layer below. After the construction of one layer was completed, the platform goes down and the extrusion nozzle constructs the other layer. This process continues until the piece is completed. PLA (Polylactic Acid) is an organic biopolymer and thermoplastic produced from corn starch and sugar cane. Therefore, it is not harmful to human health. A 3D Printer using FDM technology can make PLA print. It is slightly flexible but has a fragile structure. It is durable and resistant to impacts. New featured filaments can be obtained by mixing PLA filament with certain proportions of wood, bronze, copper, bamboo, carbon fiber and similar fibers [2-5]. 
Figure 2.3D printer filament

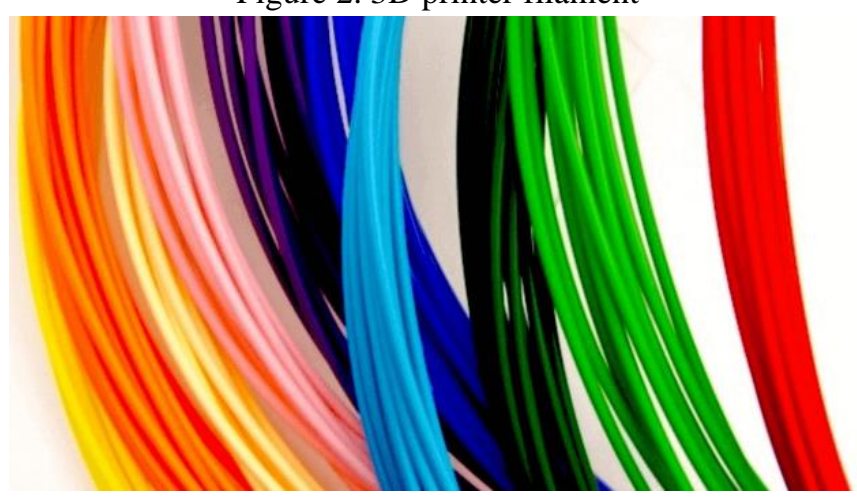

The use of these printers is for two purposes. First of all, clothes can be produced by this method as a whole (Figure 3), secondly, alternative surfaces are created with different connection forms by using the FDM method to woven or knitted surfaces that form the basis of the textile surface (Figure 4). The biggest problem is the energy problem of electronic devices when mains electricity is not accessible in business life, travels and daily life. As a solution to this, a 3D filament-integrated bag design with solar panels is created and procured that electronic devices such as mobile phones, tablets and laptops are charged with photovoltaic energy.

Figure 3. 3D filament printed surface

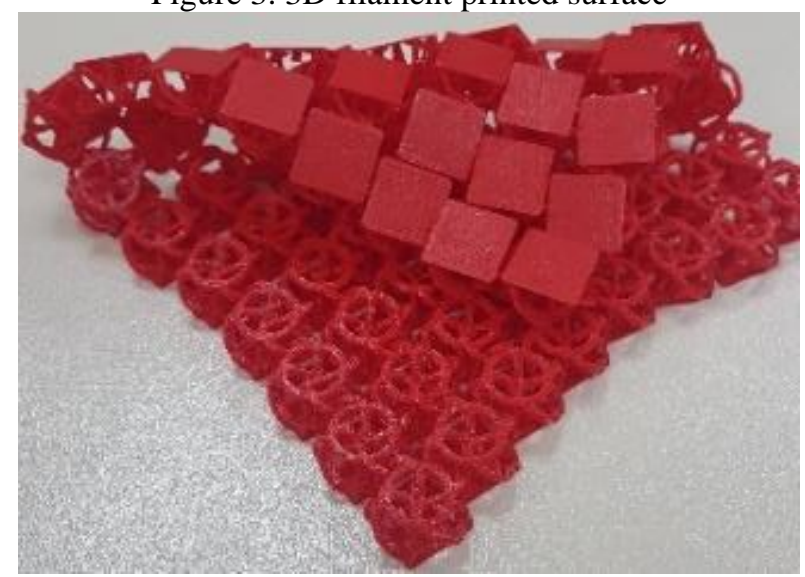


Figure 4. Integration of 3D filament into fabric

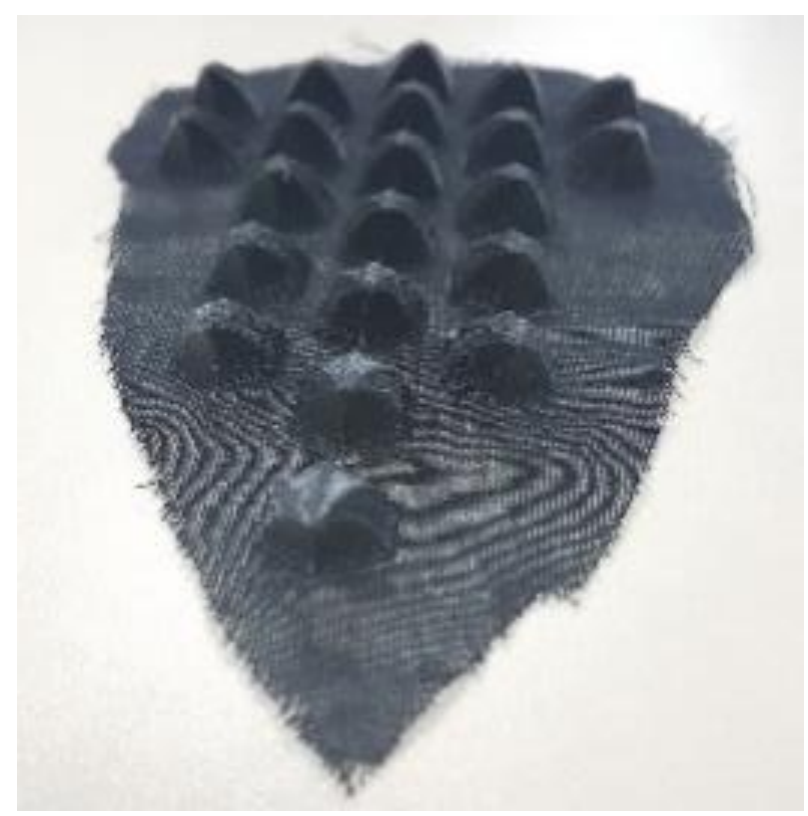

In the study, an alternative textile surface was obtained by manufacturing and integrating the collar, front part and button apparatus of the vest made of woven fabric with 3D filament (Figure 5-6).

Figure 5. 3D filament printed vest preliminary work

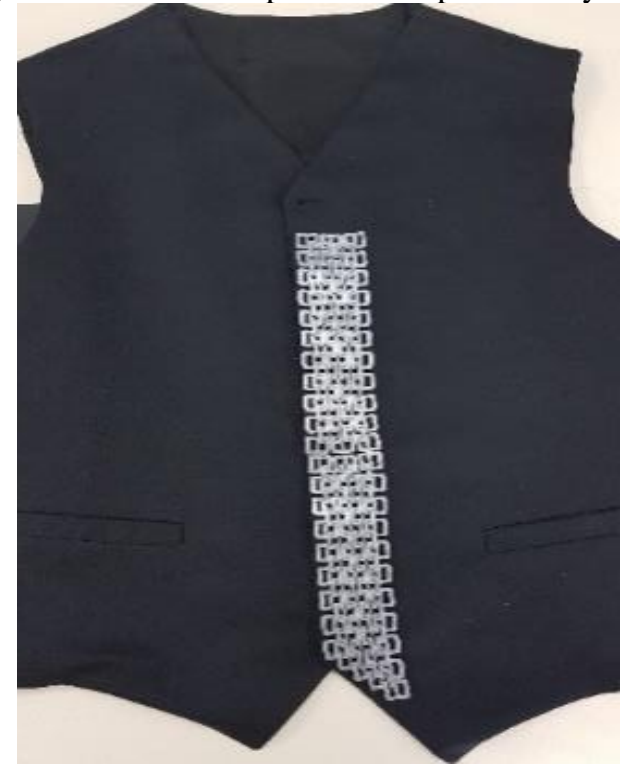




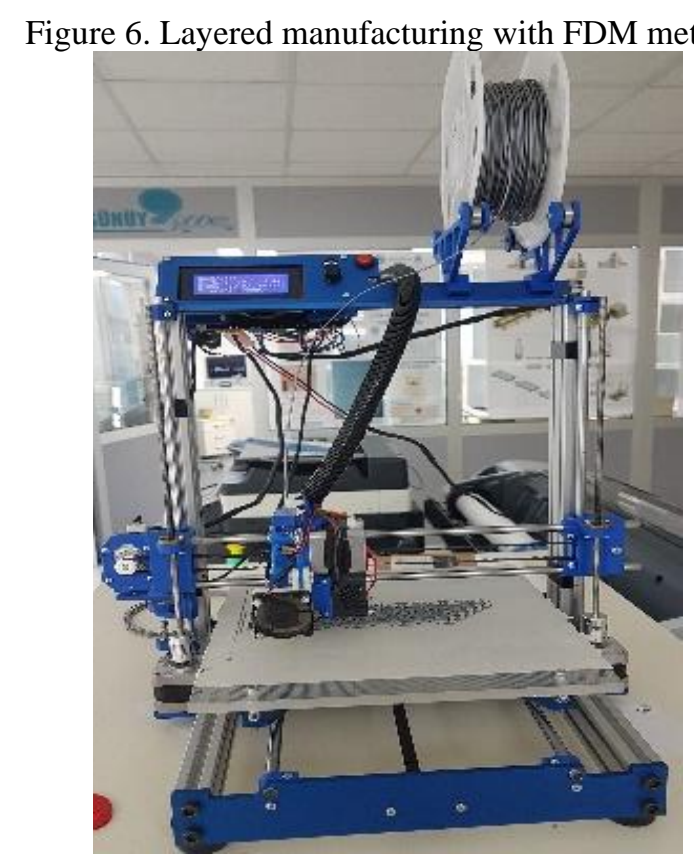

\section{CONCLUSION}

In this study, solar panels were placed inside the 3D printed material obtained by the FDM method, one of the layered manufacturing methods to integrate it into the textile material and to charge electronic devices from photovoltaic energy (Figure 7-8). Vest and bag materials were used in the study. The optimum 3D printing designs were designed on the drawing program.

Figure 7. 3D filament printed vest

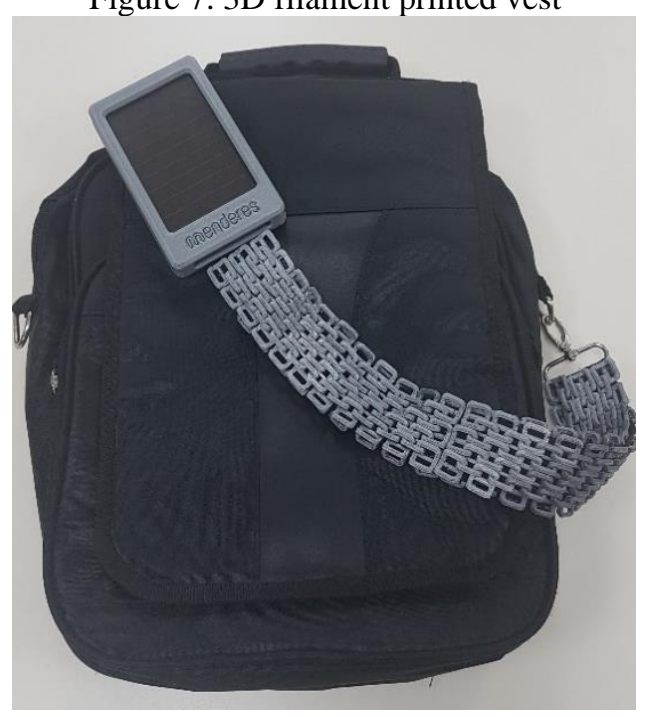


Figure 8. Bag capable of generating photovoltaic energy with 3D filaments

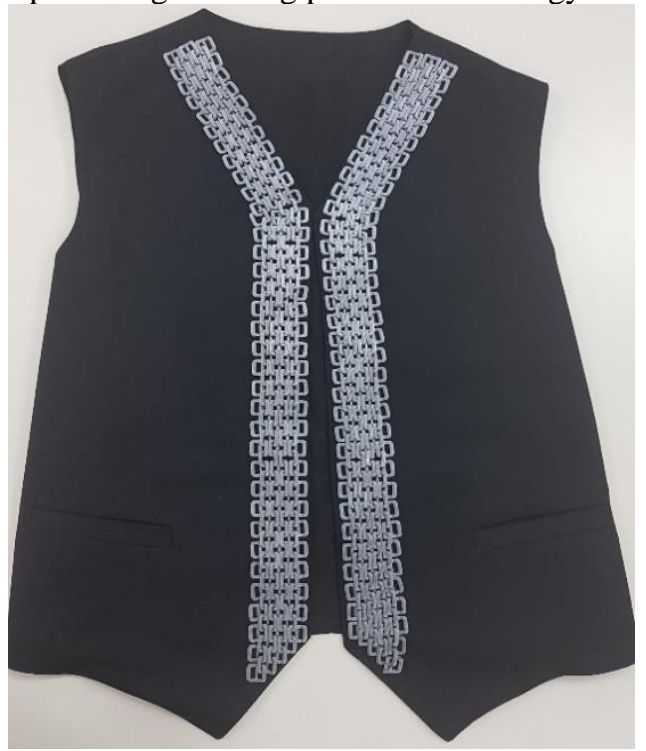

In the standard textile production process, textile material consists of many steps, which causes the waste of time, environmental pollution and energy consumption and it causes the depletion of natural resources in the following years. Foreseeable future, alternative process steps will be developed to standard textile production with 3D printers and the production of personalized clothes will be provided with $3 \mathrm{D}$ in textile manufacturing.

\section{DISCUSSION AND ASSESMENT}

Solar energy; is a clean, renewable and sustainable energy source. Therewithal, it has superiorities such as it can be applied locally, does not require complex technology and there is no environmentally hazardous waste, which is an important problem for humanity. For this reason, intensive studies have been carried out on it in recent years. Solar-powered systems can be easily moved and installed and can be easily changed depending on the energy requirement.

With the solar energy potential of Turkey and legal regulations, when performed encouraging initiatives for manufacturers and users like as many other world countries, photovoltaic technology investment and usage will be more widespread in Turkey. The application of solar cells will enable besides other applications, to apply textile and apparel products, to provide renewable energy generation, and to obtain and use various special functional smart textiles. The application of solar cells will enable besides other applications, to apply textile and apparel products, to provide renewable energy generation, and to obtain and use various special functional smart textiles. It is aimed to produce, using the knowledge gained as a result of the study, smart textile products (button device that provides communication, smart textile 
products that prevent electromagnetic waves, etc.) that facilitate human life with $3 \mathrm{D}$ printed materials obtained from filaments with conductive additive.

\section{ACKNOWLEDGEMENTS}

Thanks to Menderes R\&D Center employees and Menderes Textile Design Department employee Yusuf GÜNGÖR for their support at the data collection stage in the implementation of this study. 


\section{REFERENCES}

S.Uçar, "Teknik ve Akilli Tekstil Malzemelerinin Geleneksel (Konvansiyonel) Tekstil Ürünleri, Formlari ve Desenlerinde Uygulanmasi," Mimar Sinan Güzel Sanatlar Üniversitesi Sosyal Bilimler Enstitüsü Tekstil Ve Moda Tasarimi Anasanat Dali Tekstil Ve Moda Tasarimi Programı, Sanatta Yeterlilik Tezi, 2012.

M.Çakır, "Katmanli İmalat ve Savunma Sanayi Uygulamalarinin Araştirmasi”, Eskişehir Osmangazi Üniversitesi Mühendislik Mimarlik Fakültesi Makine Mühendisliği Bölümü, Lisans Bitirme Tezi, 2016.

A. Bedeloğlu, A. Demir, Y. Bozkurt "Fotovoltaik Teknolojisi: Türkiye ve Dünyadaki Durumu, Genel Uygulama Alanları ve Fotovoltaik Tekstiller", Tekstil Teknolojileri Elektronik Dergisi, 4(2) 43-58, 2010. A. Bedeloğlu, "Fotovoltaik Etki Olusturan Lif Gelistirilmesi", Dokuz Eylül Üniversitesi, Fen Bilimleri Enstitüsü, Doktora Tezi, 2009.

M. Yıldıran, "Moda Giyim Sektöründe Üç Boyutlu Yazicilarla Tasarim Ve Üretim”, Süleyman Demirel Üniversitesi, Güzel Sanatlar Fakültesi Hakemli Dergisi, 20 